GESTEIRA, Sérgio Martagão, SECCO, Carmen Lucia Tindó e SILVEIRA, Jorge Fernandes da. Entrevista João Melo (Angola). Revista Diadorim / Revista de Estudos Linguísticos e Literários do Programa de Pós-Graduação em Letras Vernáculas da Universidade Federal do Rio de Janeiro. Volume 11, Julho 2012. [http://www.revistadiadorim.letras.ufrj.br]

\title{
ENTREVISTA:
}

\author{
João Melo ${ }^{1}$
}

\section{Diadorim: $\mathrm{O}$ que significa poesia para você? Teria algum conceito ou teoria para defini-la?}

João Melo: A poesia, para mim, é uma forma de sobrevivência. Uma maneira de adiar a inevitável degradação do tempo, dos corpos e das relações, isto é, da existência, o que implica o posicionamento do poeta, através, ou melhor, mediante a linguagem, seja exaltando, criticando ou negando essa existência, em todas as suas manifestações. Poesia é, pois, expressão. Por isso, não creio nem possível, nem recomendável encerrá-la numa conceptualização ou teoria qualquer, o que seria castrá-la, uma vez que, sendo a realidade polissêmica, é sempre percebida de vários modos e exige diferentes formas de expressão. Tenho um poema em que digo o seguinte: - "Não tenho escolas / nem gurus. / A linha da poesia/ é a linha da vida”.

\section{Diadorim: Considerando a literatura e as artes em geral, o que pensa sobre o estabelecimento e a revisão do cânone?}

JM: Feliz ou infelizmente, a literatura e as artes em geral possuem um aspecto institucional incontornável. Em todas as sociedades, existem instâncias que legitimam a literatura e as artes, estabelecendo o seu chamado valor cultural e definindo, por conseguinte, o cânone. Tais instâncias podem ser culturais, acadêmicas, jornalísticas, ideológicas, políticas, mercadológicas ou quaisquer outras, as quais muitas vezes se entrecruzam e misturam entre si. A fixação do cânone é feita por essas instâncias de maneira unilateral, o que remete à questão do poder: cânone é poder. Por essa razão, ocorrem mais ou menos periodicamente processos de revisão do cânone, quando a correlação de forças muda. Acho que o cânone ocidental, neste momento, está em crise, assistindo-se a um confronto entre duas tendências: o

1. Poeta, escritor e jornalista angolano [joaomelo@africa-21.com] 
esvaziamento da capacidade de comunicação da literatura, em nome de um esplendor formal muitas vezes gratuito, uma erudição superficial e uma intertextualidade exibicionista, e o seu empobrecimento ou mesmo imbecilização. Daí a curiosidade pela literatura originária de outros universos (e que não se limite a ser uma cópia desse cânone, o que, por causa da globalização, é mais frequente do que seria desejável). Por fim, parece necessário acrescentar que a relação entre os escritores e produtores culturais e o cânone é sempre problemática. Alguns tornam-se escravos do cânone, outros continuam teimosamente a escrever, sem medo de permanecerem desconhecidos ou eternamente desvalorizados, e muitos, talvez a maioria, desistem.

\section{Diadorim: Como vê essa mesma questão no percurso da literatura de seu país?}

JM: Em Angola não existe uma tradição acadêmica digna desse nome e os críticos literários a sério não perfazem os cinco dedos de uma mão. Mas há uma tradição histórica e política peculiar: muitos escritores estão entre aqueles que iniciaram a luta pela independência do país. O primeiro presidente do país, Agostinho Neto, por exemplo, foi um poeta consagrado. Por isso, o cânone literário angolano começou por ter uma conotação política muito evidente, bem como as reações e as tentativas de crítica ou revisão desse cânone. Assim, se nos primeiros anos de independência a tendência foi valorizar, muitas vezes injustificadamente, todos os escritores ligados à luta nacionalista e ao partido que conquistou a independência, o MPLA, assim como um certo tipo de literatura "comprometida", à medida que os anos foram passando e a situação política mudando, assistiu-se a tentativas de excluir do cânone verdadeiros escritores, apenas por fazerem literatura política e/ou estarem politicamente ligados ao MPLA. Ainda hoje, organizadores de certas antologias deixam deliberadamente de fora autores importantes da literatura angolana, devido a esses parti-pris. Assiste-se também a outra tendência verdadeiramente nefasta: a promoção da mediocridade e o nivelamento por baixo operado pelos meios de comunicação. Essa situação, espero, poderá ser superada, quando existir no país uma verdadeira e sólida crítica literária. Por enquanto, e devido a todas essas razões, talvez não seja errado afirmar que o cânone literário angolano propriamente dito tem sido estabelecido, até agora, mais por instâncias externas do que internas. Destaco dois países: Portugal e Brasil. No primeiro, a "legitimação" da literatura angolana tem sido realizada, sobretudo, por certas editoras e pela mídia (nesse sentido, o papel da academia portuguesa tem sido subsidiário), cada qual com a sua limitação: as escolhas demasiado seletivas das editoras, que ignoram autores de qualidade jamais editados no exterior, e os preconceitos político-ideológicos da maioria dos jornalistas portugueses, que tendem a valorizar muito mais os autores abertamente críticos ou opositores do atual governo angolano, dirigido pelo MPLA. Quanto ao Brasil, é o país que produz a mais importante crítica acadêmica acerca da literatura de Angola, em quantidade e quali- 
dade, contribuindo também para o estabelecimento do cânone angolano, de uma maneira altamente profissional. Mas os autores angolanos precisam de maior acesso ao mercado e à mídia brasileira.

\section{Diadorim: Gostaria de deter-se em algum poeta em particular?}

JM: Prefiro mencionar - e homenagear aqui - não apenas um, mas um vasto grupo de poetas que contribuiram, cada qual de uma maneira, para a minha formação poética. São eles: os angolanos Mário António, António Jacinto, Agostinho Neto, Viriato da Cruz e Cândido da Velha; os portugueses António Ramos-Rosa, Ruy Belo, Mário Cesariny, Carlos de Oliveira, Alexandre O’Neill, Daniel Filipe e Manuel Alegre; os moçambicanos Noémia de Sousa e José Craveirinha; os brasileiros Manuel Bandeira, Jorge de Lima e João Cabral de Melo Neto; o chileno Pablo Neruda; o cubano Nicolas Guillén; o russo Maiakovsky; o espanhol García Lorca; o alemão Bertolt Brecht; e o francês Paul Éluard.

Diadorim: Como vê a questão, ou melhor, a divisão dos gêneros canônicos hoje? E, "ça va sans dire", cânone e geração internet, blogue, cibernética... Há, “de fato", uma novíssima poesia em seu país?

JM: Confesso que essa questão não me preocupa muito, para não dizer, mesmo, nada. Aliás, continuo a escrever os meus poemas manualmente, pois a poesia, para mim, tem algo de visceral, logo, tem de ser feita naturalmente. O poeta deve ser um artesão e, quando escreve, devem doer-lhe não apenas o espírito e a alma, mas as mãos. Um bom poema tem de sangrar nas mãos. Encaro as novas tecnologias como meios de comunicação, que podem e devem ser usados para difundir a poesia, mas não mais do que isso. Não me aventuro a fazer poesia digital. Nesse sentido, só vejo um poeta em Angola que transita com desenvoltura e arrojo entre o texto, a linguagem digital e as artes plásticas: Frederico Ningi. Mal comparando, é uma espécie de "Ricardo Aleixo angolano".

\section{Entrevista recebida em 03 novembro de 2011.}

